\title{
KEPUASAN KERJA DAN KOMITMEN ORGANISASIONAL BERPENGARUH TERHADAP KINERJA KARYAWAN
}

\author{
Nuryanti ${ }^{1}$ \\ Desak Ketut Sintaasih ${ }^{2}$
}

Fakultas Ekonomi Dan Bisnis Universitas Udayana (Unud), Bali, Indonesia
email:Nuryantisadalin@gmail.com

\begin{abstract}
ABSTRAK
Kinerja karyawan merupakan aspek yang sangat penting bagi keberhasilan organisasi. Tujuan penelitian ini adalah untuk menganalisis pengaruh kepuasan kerja dan komitmen organisasional terhadap kinerja karyawan di PT. Pos Indonesia cabang Denpasar. Populasi dalam penelitian ini seluruh karyawan yang berjumlah 413 orang dengan mengambil sampel sebanyak 50 orang yang mengacu pada Roscoe. Jenis data yang digunakan meliputi data kuantitatif dan kualitatif, sedangkan sumber data adalah data primer dan sekunder. Teknik analis data yang digunakan adalah regresi linear berganda. Dari hasil pengujian hipotesis diperoleh hasil bahwa kepuasan kerja dan komitmen organisasional berpengaruh positif dan signifikan terhadap kinerja karyawan di PT. Pos Indonesia cabang Denpasar.
\end{abstract}

Kata Kunci: kepuasan Kerja, Komitmen Organisasional dan Kinerja Karyawan

\begin{abstract}
Employee performance is a very important aspect for organizational sccess. The purpose of this study was to analyze the effect of job satisfaction and organizational commitment on employee performance at PT. Pos Indonesia branch Denpasar. The population in this study all employees amounted to 413 people by taking a sample of 50 people who refer to Roscoe. The type of data used includes quantitative and qualitative data, while the data sources are primary and secondary data. The data analysis technique used is multiple linear regression. From the results of hypothesis testing the results show that job satisfaction and organizational commitment have a positive and significant effect on employee performance at PT. Pos Indonesia branch Denpasar.

Keywords: Job satisfaction, organizational commitment and employee performance
\end{abstract}




\section{PENDAHULUAN}

Sumber daya manusia (SDM) merupakan salah satu bagian penting dalam suatu organisasi. Organisasi dikatakan berhasil atau tidak dalam mencapai tujuannya ditentukan oleh kinerja karyawan. Pentingnya sumber daya manusia yang berkualitas dalam dunia layanan sudah menjadi keharusan, mengingat persaingan dalam industri layanan, terlebih lagi ketika tantangan yang dirasakan semakin lama semakin kompleks. PT.Pos Indonesia memiliki keinginan dalam keunggulan bersaing, menuntut mereka untuk selalu meningkatkan kualitas sumber daya yang dimiliki, sedangkan kualitas sumber daya manusia banyak ditentukan oleh sejauh mana sistem yang berlaku, sanggup menunjang dan memuaskan keinginan karyawan maupun perusahaan.

Pasang surut mewarnai perjalanan panjang dua setengah abad Pos Indonesia. Masa-masa keemasan industri perposan ada di tahun-tahun 1970 hingga 1980-an. Masyarakat pengguna jasa pos cenderung nyaman memakai jasa layanan pos, dikarenakan keamanan yang selalu di tawarkan kepada konsumennya sehingga konsumen percaya untuk menggunakan jasa layanan ini. Seperti juga dialami banyak perusahaan pos di dunia, Pos Indonesia sempat mengalami penurunan kinerja pada tahun 2011-2013. PT. Pos Indonesia cabang Denpasar di tahun-tahun tersebut menurun drastis.

Selanjutnya untuk penilaian kinerja karyawan PT Pos Indonesia, dapat dilihat dari Data Nilai SMKI (Sistem Manajemen Kinerja Individu) tahun 2011 2013 yaitu sebagai berikut:

\section{Tabel 1.}

Pencapaian kinerja karyawan PT Pos Indonesia tahun 2011 -2013

\begin{tabular}{llllll}
\hline Triwulan & KPI & Triwulan & KPI & Triwulan & KPI \\
\hline TW1 & $51 \%$ & TW1 & $73 \%$ & TW1 & $63 \%$ \\
TW2 & $70 \%$ & TW2 & $84 \%$ & TW2 & $56 \%$ \\
TW3 & $60 \%$ & TW3 & $78 \%$ & TW3 & $72 \%$ \\
TW4 & $81 \%$ & TW4 & $68 \%$ & TW4 & $75 \%$ \\
\hline
\end{tabular}

Sumber: Divisi Pelayanan PT Pos Indonesia (Persero) Kantor Pusat Denpasar, 2019

Penilaian Sistem Manajemen Kinerja Individu (SMKI) yang digunakan oleh PT Pos Indonesia (Persero) Denpasar disebut dengan Key Performace Indicator (KPI) dalam bentuk persentase ketercapaian kinerja yang dilakukan setiap 3 bulan sekali Menurut Keputusan Direksi PT. Pos Indonesia No: KD. 15/DIRUT/0210 Tentang Sistem Manajemen Kinerja Individu, KPI adalah penilaian kinerja yang digunakan untuk membantu perusahaan menentukan dan mengukur kemajuan terhadap sasaran setiap anggota. Aspek-aspek yang digunakan dalam mengukur Key Performace Indicator (KPI) mencakup kualitas kerja, kuantitas kerja, dan tingkat kehadiran karyawan. 
Bila tabel rekapitulasi di atas digambarkan, maka akan terlihat grafik sebagai beriku

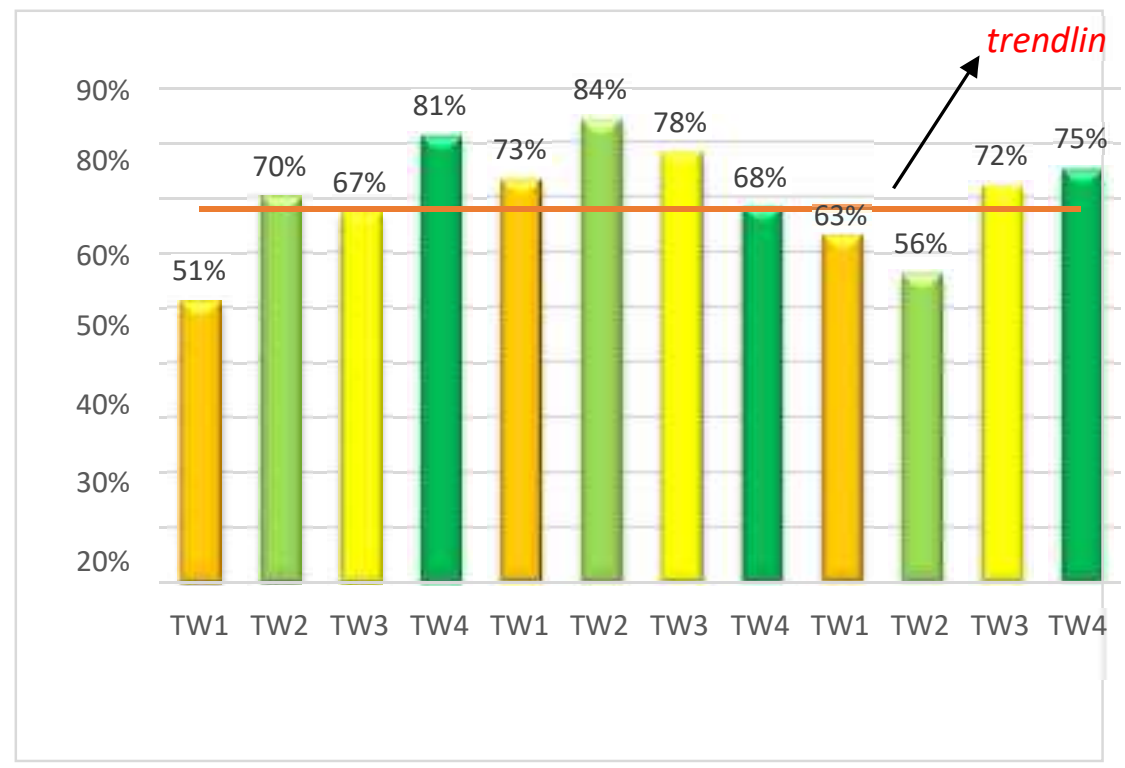

\section{Gambar 1. Grafik pencapaian kinerja karyawan PT Pos Indonesia tahun $2011-2013$}

Penilaian Sistem Manajemen Kinerja Individu (SMKI) yang digunakan oleh PT Pos Indonesia (Persero) Denpasar disebut dengan Key Performace Indicator (KPI) dalam bentuk persentase ketercapaian kinerja yang dilakukan setiap 3 bulan sekali. Menurut Keputusan Direksi PT. Pos Indonesia No: KD. 15/DIRUT/0210 Tentang Sistem Manajemen Kinerja Individu, KPI adalah penilaian kinerja yang digunakan untuk membantu perusahaan menentukan dan mengukur kemajuan terhadap sasaran setiap anggota. Aspek-aspek yang digunakan dalam mengukur Key Performace Indicator (KPI) mencakup kualitas kerja, kuantitas kerja, dan tingkat kehadiran karyawan.

Pada tabel rekapitulasi di atas menunjukkan pencapaian kinerja karyawan PT Pos Indonesia mengalami fluktuasi dari tahun 2011 - 2013. Ditahun 2011 pada triwulan 1 pencapaian kinerja karyawan mencapai $51 \%$ dan terjadi kenaikan pada triwulan 2 sebesar $70 \%$, namun pada triwulan 3 terjadi penurunan menjadi $67 \%$ kemudian di triwulan 4 kembali terjadi kenaikan pencapaian kinerja menjadi $81 \%$. Pada tahun 2012, ditriwulan 1 pencapaian kinerja karyawannya mencapai angka 73\% kemudian terjadi kenaikan pada triwulan 2 menjadi 84\% namun pada triwulan 3 pencapaian kinerja karyawan mengalami penurunan menjadi $78 \%$. Pada triwulan 4 kembali terjadi penurunan pencapaian kinerja karyawan sebesar 10\% sehingga menjadi 68\%. Tahun 2013 triwulan 1 pencapaian kinerja karyawan PT Pos Indonesia adalah sebesar $63 \%$ namun terjadi penurunan menjadi $56 \%$ pada triwulan 2 kemudian pada triwulan 3 dan 4 terjadi kenaikan sebesar $72 \%$ dan 75\%. Pada data tersebut terdapat garis merah yang disebut trendline, trendline 
menggambarkan garis yang cenderung stabil setiap tahunnya, sehingga dapat disimpulkan bahwa pencapaian kinerja pada PT Pos Indonesia Denpasar tidak mengalami kenaikan yang signifikan berdasarkan trendline.

Dari informasi yang didapatkan dari hasil wawancara peneliti dengan manajer di bagian Divisi Pelayanan PT Pos Indonesia Denpasar diketahui bahwa realisasi pencapaian kinerja karyawan diatas belum optimal karena belum memenuhi target yang ditetapkan PT Pos Indonesia sebesar 100\%. Ketercapaian target $100 \%$ diartikan bahwa karyawan mampu memenuhi semua tugas yang ditugaskan kepada mereka dalam bentuk program kerja.

Pada survey didapatkan data berupa jumlah karyawan yang mangkir pada PT Pos Indonesia tahun 2011 - 2014 seperti terlihat pada Tabel 2.

Tabel 2.

Tingkat kemangkiran karyawan PT Pos Indonesia Denpasar tahun 2011 - 2014

\begin{tabular}{cc}
\hline Tahun & Kemangkiran karyawan (orang) \\
\hline 2011 & 25 \\
2012 & 46 \\
2013 & 50 \\
2014 & 35 \\
\hline
\end{tabular}

Sumber: Divisi CMO PT Pos Indonesia Kantor Pusat Denpasar, 2019

Data pada Tabel 2. menunjukkan tingkat kemangkiran karyawan PT Pos Indonesia pada tahun 2011 - 2014 mengalami fluktuasi setiap tahunnya. Dapat dilihat, pada tahun 2011 jumlah karyawan yang mangkir mencapai 25 orang atau sekitar $16 \%$. Terjadi kenaikan kemangkiran karyawan selama 2 tahun berturutturut dari tahun 2012 hingga tahun 2013 yaitu sebesar 46 orang atau 30\% dan sebesar 50 orang atau sekitar 32\%. Pada tahun 2014 jumlah kemangkiran karyawan mengalami penurunan menjadi 35 orang atau sekitar $22 \%$.

Rumusan masalah dalam penelitian ini adalah 1). Apakah kepuasan kerja berpengaruh positif terhadap kinerja karyawan pada PT. Pos Indonesia.? 2). Apakah komitmen organisasional berpengaruh positif terhadap kinerja karyawan pada PT. Pos Indonesia.? 3). Apakah kepuasan kerja dan komitmen organisasional berpengaruh positif terhadap kinerja karyawan pada PT. Pos Indonesia.?

Tujuan penelitian yang ingin di capai adalah 1). Menguji dan memberikan bukti empiris pengaruh kepuasan kerja terhadap kinerja karyawan pada PT. Pos Indonesia. 2). Menguji dan memberikan bukti empiris pengaruh komitmen organisasional terhadap kinerja karyawan pada PT. Pos Indonesia. 3). Menguji dan memberikan bukti empiris pengaruh kepuasan kerja dan komitmen organisasional terhadap kinerja karyawan pada PT. Pos Indonesia.

Penelitian ini diharapkan dapat memberikan manfaat baik secara praktis maupun teoritis. Adapun manfaat penelitian ini yaitu: 1) kegunaan teoritis

Penelitian ini diharapkan dapat memberikan tambahan informasi bagi pimpinan organisasi dalam menilai gambaran kepuasan kerja karyawannya, peningkatan komitmen organisasional dalam rangka mempertahankan dan meningkatkan kinerja karyawan. 2). kegunaan praktis penelitian ini diharapkan dapat 
memberikan tambahan referensi dan memperkaya hasil penelitian atau peningkatan ilmu pengetahuan khususnya Sumber Daya Manusia.

Menurut Mangkunegara (2013) kinerja adalah hasil kerja orang secara kualitas dan kuantitas yang dicapai oleh seorang karyawan dalam melaksanakan tugasnya sesuai dengan tanggung jawab yang diberikan kepadanya dalam kurun waktu ditetapkan. Hal ini berarti kinerja karyawan ialah ukuran yang dapat dijadikan aspek penilaian produktifitas dari seorang karyawan. Kinerja dalam berhubungan dengan kepuasan menunjukkan kepuasan kerja berpengaruh positif dan signifikan terhadap kinerja karyawan (Artadi, 2015). Karyawan yang merasa puas akan lebih mungkin terlibat dalam organisasi yang dapat meningkatkan produktivitas, sedangkan karyawan yang merasa tidak puas akan mempengaruhi aktivitas organisasi dalam pencapaian tujuan.

Menurut Bangun, (2012) terdapat 5 aspek dalam mengukur kinerja karyawan yaitu: pertama, jumlah pekerjaan. Dimensi ini menunjukkan tentang jumlah pekerjaan yang dihasilkan oleh setiap individu.bekerja sesuai dengan kemampuan dan keahlian yang dimiliki. Berdasarkan persyaratan tersebut perusahaan bisa mengetahui jumlah karyawan yang dibutuhkan untuk melakukan tugasnya dan jumlah unit yang bisa diselesaikannya. Kedua kualitas pekerjaan. Setiap karyawan harus memenuhi persyaratan tertentu untuk dapat menghasilkan pekerjaan yang sesuai dengan kualitas yang diharapkan oleh perusahaan. Setiap pekerjaan mempunyai standar kualitas tertentu yang harus disesuaikan oleh karyawan. Karyawan akan memiliki kinerja yang baik bila dapat mengerjakan pekerjaan sesuai dengan standar kualitas yang ditetapkannya. Ketiga ketepatan waktu. Jenis pekerjaan tertentu memiliki batas waktu dalam penyelesaian pekerjaan. Bila pekerjaan tidak terselesaikan sesuai dengan waktu yang ditentukan maka akan menghambat pekerjaan lainnya. Sehingga bisa mempengaruhi jumlah dan kualitas hasil pekerjaan.Suatu jenis produk tertentu hanya dapat digunakan sampai batas waktu tertentu, ini menuntut agar diselesaikan tepat waktu, karena berpengaruh atas penggunaanya. Pada dimensi ini karyawan dituntut untuk menyelesaikan pekerjaan tepat waktu. Keempat kehadiran. Suatu jenis pekerjaan tertentu menuntut kehadiran karyawan dalam mengerjakan sesuai dengan waktu yang ditentukan. Ada beberapa pekerjaan yang menuntut kehadiran karyawan selama 8 jam perhari dalam 5 hari kerja. Kinerja karyawan ditentukan tingkat kehadiran karyawan dalam mengerjakannya. Kelima kemampuan kerja sama. Tidak semua pekerjaan dapat diselesaikan oleh satu orang saja. Ada pekerjaan yang harus dikerjakan secara berkelompok, sehingga membutuhkan kerja sama yang baik untuk menyelesaikannya. Kinerja karyawan dapat dinilai dari kemampuan dalam berkerjasama dengan rekan sekerja lainnya

Menurut Mohamed \& Anisa (2012), komitmen organisasional mengarah pada kesiapan seorang karyawan dalam merealisasikan standar, tujuan, prinsip, nilai-nilai dan etika organisasi untuk bertahan dalam organisasi baik pada situasi dan kondisi apapun.

Menurut Meyer \& Allen (1997) Komitmen organisasional dibedakan menjadi 3 dimensi yaitu: pertama, komitmen afektif (affective commitment), yang berkaitan dengan emosional, identifikasi, dan keterlibatan pegawai di suatu organisasi. Kedua, komitmen berkesinambungan (continuance commitment), pada 
persepsi pegawai tentang kerugian yang akan dihadapinya jika karyawan meninggalkan organisasi. Ketiga, komitmen normatif (normative commitment), yang merupakan perasaan-perasaan pegawai tentang kewajiban yang harus dia berikan kepada organisasi, dan tindakan tersebut merupakan hal benar yang harus dilakukan. Karyawan dengan komitmen normatif yang kuat akan tetap bergabung dalam organisasi karena mereka sudah merasa cukup dengan hidupnya.

Kepuasan kerja adalah penilaian dari pekerja tentang seberapa jauh pekerjaannya secara keseluruhan memuaskan kebutuhannya (Zainal et al., 2014). Kepuasan kerja merupakan hal penting yang dimiliki individu di dalam bekerja, dimana setiap individu pekerja memiliki karakteristik yang berbeda - beda, maka tingkat kepuasan kerjanya pun berbeda - beda pula (Priansa, 2014). Imam et al., (2013) menyatakan bahwa terdapat pengaruh positif kepuasan kerja terhadap komitmen organisasional karyawan. Tingkat kepuasan kerja masing-masing individu berbeda. Kepuasan kerja karyawan tergantung pada apa yang diharapkan dengan apa yang diterima. Tinggi rendahnya tingkat kepuasan kerja berkaitan dengan aspek fisik dalam melaksanakan kerja, kondisi lingkungan pekerjaannya, rekan kerja dan interaksinya.

Indikator-indikator kepuasan kerja menurut Robbins \& Judge (2015) yaitu: pertama, kesesuaian kepribadian dengan pekerjaan, teori "kesesuaian kepribadian-pekerjaan" Holland menyimpulkan bahwa kecocokan yang tinggi antara kepribadian seorang karyawan dan okupasi akan menghasilkan seorang individu yang lebih terpuaskan. Orang-orang dengan tipe kepribadian yang sama dengan pekerjaannya memiliki kemungkinan yang besar untuk berhasil dalam pekerjaannya, sehingga mereka juga akan mendapatkan kepuasan yang tinggi. Kedua, kondisi kerja yang mendukung karyawan peduli akan lingkungan yang baik untuk kenyamanan pribadi maupun untuk mempermudah mengerjakan tugas yang baik. Studi-studi membuktikan bahwa karyawan lebih menyukai keadaan sekitar yang aman, tidak berbahaya dan tidak merepotkan. Di samping itu, kebanyakan karyawan lebih menyukai bekerja dekat dengan rumah, dalam fasilitas yang bersih dan relatif modern, dan dengan alat-alat yang memadai. Ketiga, gaji atau upah yang pantas, para karyawan menginginkan sistem upah dan kebijakan promosi yang mereka resepsikan sebagaia adil dan segaris dengan penghargaan 13 mereka Bila upah sebagai adil yang didasarkan pada tuntuttan pekerjaan, tingkat keterampilan individu, dan standar pengupahan komunitas, kemungkinan besar akan dihasilkan kepusasan. Promosi meberikan kesempatan untk pertumbuhan pribadi, tanggungjawab yang lebih banyak, dan status sosial yang ditingkatkan. Oleh karena itu, individu-individu yang mempersepsikan bahwa keputusan promosi dibuat secara adil, kemungkina besar karyawan akan mengalami kepuasan dalam pekerjaannya. Keempat, kesempatan promosi jabatan, karyawan cenderung lebih menyukai pekerjaan yang memberikan pelatihan dalam pengembangan karir yang jelas dan peluang untuk maju, kestabilan perusahaan dan moral kayawan yang akan lebih terjamin. Kelima rekan sekerja yang mendukung, bagi kebanyakan karyawan, bekerja juga mengisi kebutuhan akan interaksi sosial. Oleh karena itu, tidaklah mengejutkan apabila mempunyai rekan sekerja yang ramah dan mendukung akan mengarah ke kepuasan kerja yang meningkat. 
Berdasarkan kajian pustaka yang dipaparkan di atas maka dapat di gambarkan kerangka konseptual penelitian sebagai berikut:

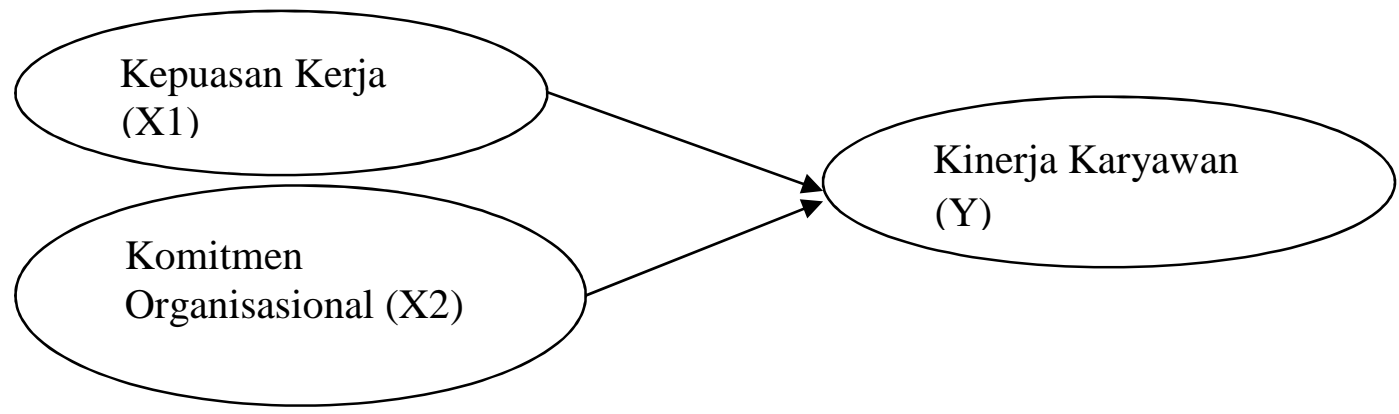

Gambar. 2 Kerangka Konseptual

Hipotesis dalam penelitian ini dibangun berdasarkan kajian pustaka yang mendukung dan beberapa hasil penelitian sebelumnya bahwa kinerja karyawan dipengaruhi oleh beberapa faktor antara lain adalah kepuasan kerja dan komitmen organisasional.

Kepuasan kerja merupakan salah satu faktor penting untuk mendapatkan hasil kerja yang optimal. Karyawan yang merasakan kepuasan kerja dalam pekerjaannya akan melakukan pekerjaanya dengan baik. Dalam penelitian Artadi (2015) dalam penelitiannya tentang pengaruh kepuasan kerja dan beban kerja terhadap kinerja karyawan pada PT. Merapi Agung Lestari memperoleh hasil bahwa kepuasan kerja berpengaruh positif gerhadap kinerja karyawan.

Aji (2012) dengan judul pengaruh kepuasan kerja, loyalitas karyawan, dan komitmen organisasi terhadap kinerja karyawan (Studi kasus pada PT. Vision Land Bagian Packing) menunjukan bahwa kepuasan kerja berpengaruh positif terhadap kinerja karyawan. Indriani \& Wisnu (2011) dengan judul pengaruh budaya organisasi dan kepuasan kerja terhadap kinerja karyawan dengan komitmen organisasi sebagai variabel intervening pada Workshop SMK Katolik Santo Mikael Surakarta.

Hasil dari penelitian ini membuktikan bahwa kepuasan kerja berpengaruh positif terhadap kinerja karyawan. Dengan adanya penelitian ini diharapkan perusahaan dapat mengetahui pengaruh tingkat kepuasan kerja karyawan terhadap tingkat kinerja karyawan.

Kepuasan kerja memperlihatkan keadaan emosional karyawan terhadap perusahaan. Karyawan yang merasa puas dengan pekerjaanya akan termotivasi dalam bekerja. Kemudian akan meningkatkan kinerja karyawan PT. Pos Indonesia. Jika kepuasan kerja karyawan meningkat maka kinerja karyawan juga akan meningkat. Untuk itu perlu bagi perusahaan untuk memperhatikan kepuasan kerja yang dimiliki oleh karyawan..

$\mathrm{H}_{1}$ : kepuasan kerja berpengaruh signifikan terhadap kinerja karyawan pada PT.

Pos Indonesia cabang Denpasar.

Komitmen organisasi merupakan komitmen yang dimiliki seorang karyawan terhadap perusahaan dimana karyawan tersebut bekerja. Kristiwardhana (2011) dalam penelitiannya yang berjudul analisis pengaruh motivasi dan 
komitmren organisasional terhadap kinerja. Aryo menyatakan dalam penelitiannya bahwa komitmen organisasional berpengaruh positif terhadap kinerja.

Desmiyawati \& Witaliza (2012) menyatakan bahwa komitmen organisasi, pengendalian intern dan akuntabilitas publik memiliki pengaruh yang signifikan terhadap kinerja karyawan (Studi Rumah sakit swasta di Propinsi Riau). Karyawan yang peduli terhadap nasib perusahaan tidak akan melanggar peraturan yang ditetapkan oleh perusahaan karena dapat merugikan perusahaan dan karyawan yang lain. Dalam penelitian yang dilakukan oleh Verawati \& Utomo (2011) dengan judul pengaruh komitmen organisasional, partisipasi dan motivasi terhadap kinerja karyawan menyatakan bahwa komitmen organisasional berpengaruh positif dan signifikan terhadap kinerja karyawan di PT. Bank Lippo Cabang Kudus.

Timbal balik yang positif tersebut adalah karyawan akan bekerja sebaik mungkin untuk kemajuan dan keberlangsungan perusahaan dimana karyawan tersebut bekerja. Perusahaan dan karyawan yang memiliki komitmen memiliki kesamaan nilai oleh karena itu memiliki tujuan yang sama. Karyawan merasa nyaman bekerja dalam perusahaan dan akan memeberikan kinerja terbaiknya. Apabila komitmen yang dimiliki karyawan meningkat maka kinerja karyawan juga meningkat.

$\mathrm{H}_{2}$ : Komitmen organisasisional berpengaruh signifikan terhadap kinerja karyawan pada PT. Pos Indonesia cabang Denpasar.

\section{METODE PENELITIAN}

Dalam penelitian ini, peneliti menggunakan metode kuantitatif. Jenis pendekatan yang peneliti gunakan adalah jenis pendekatan analisis deskripsi kuantitati. Adapun penelitian yang dilakukan kali ini adalah penelitian penjelasan dengan menggunakan metode survey yang mana dalam pengumpulan datanya digunaka kuesioner dan wawancara. Penelitian ini bertujuan untuk mengetahui pendapat responden, data yang akan diperoleh dari pengambilan sampel dalam populasi yang akan di teliti. Adapun penelitian yang bersifat explanatory dalam penelitian ini yaitu pengaruh kepuasan dan komitmen organisasional terhadap kinerja karyawan. Lokasi penelitian ini tepatnya di PT. Pos Indonesia Jl.Raya Puputan no.37 Renon, Denpasar, Bali. Obyek penelitian ini adalah model hubungan kepuasan kerja dan komitmen organisaisonal dengan kinerja individu karyawan pada semua Bidang pada PT. Pos Indonesia Cabang Denpasar.

Lokasi penelitian ini dilakukan di kantor pusat PT.Pos Indonesia Cabang Denpasar yang terletak di Jl.Raya Puputan no.37 Renon, Denpasar, Bali. Lokasi ini dipilih karna kinerja karyawan di PT. Pos Indonesia mengalami fluktuasi setiap tahunnya, sehingga penulis ingin menguji kepuasan kerja dan komitmen organisasional terhadap kinerja karyawan

Variabel-variabel dalam penelitian ini diidentifikasi sebagai variabel bebas dan terikat. Variabel bebas adalah variabel yang mempengaruhi kinerja atau yang menjadi sebab terjadinya perubahan pada variabel dependen. Variabel terikat adalah variabel yang dipengaruhi atau yang menjadi akibat adanya variabel bebas. 
Definisi operasional dari setiap variabel yang akan di teliti dijelaskan, kepuasan kerja $\left(\mathrm{X}_{1}\right)$ merupakan sikap umum karyawan terhadap pekerjaannya yang menunjukkan perbedaan antara jumlah penghargaan yang diterima karyawan dengan jumlah yang seharusnya mereka terima (Robbins \& Judge, 2015). Indikator-indikator yang menentukan kepuasan kerja yaitu Robbins \& Judge, (2015) : 1) Kesesuaian kepribadian dengan pekerjaan teori "kesesuaian kepribadian-pekerjaan" Holland menyimpulkan bahwa kecocokan yang tinggi antara kepribadian seorang karyawan dan okupasi akan menghasilkan seorang individu yang lebih terpuaskan. 2) kondisi kerja yang mendukung karyawan peduli akan lingkungan yang baik untuk kenyamanan pribadi maupun untuk mempermudah mengerjakan tugas yang baik. Studi-studi membuktikan bahwa karyawan lebih menyukai keadaan sekitar yang aman, tidak berbahaya dan tidak merepotkan. 3) gaji atau upah yang pantas bila upah dilihat sebagai adil yang didasarkan pada tuntutan pekerjaan tingkat keterampilan individu, dan standar pengupahan komunitas kemungkinan besar akan dihasilkan kepuasan kerja .

4) kesempatan promosi jabatan karyawan cenderung lebih menyukai pekerjaan yang memberikan pelatihan dalam pengembangan karir yang jelas dan peluang untuk maju, 5) Rekan kerja yang mendukung bagi kebanyakan karyawan, bekerja juga mengisi kebutuhan akan interaksi sosial. Oleh karena itu, tidaklah mengejutkan apabila mempunyai rekan sekerja yang ramah dan mendukung akan mengarah ke kepuasan kerja yang meningkat. Menurut Meyer \& Allen (1997) merumuskan tiga dimensi dalam berorganisasi, yaitu: a). affective commitment berkaitan dengan hubungan emosional anggota terhadap organisasinya, identifikasi dengan organisasi dan keterlibatan anggota dengan kegiatan di organisasi. b). Continuance Commitment berkaitan dengan kesadaran anggota organisasi akan mengalami kerugian jika meninggalkan organisasi. c). normative commitment menggambarkan perasaan keterikatan untuk terus berada dalam organisasi. Kinerja Karyawan (Y) Menurut Bangun, (2012) menyatakan penilai kinerja karyawan, standar pekerjaan harus dapat diukur dan dipahami secara jelas. Suatu pekerjaan dapat diukur melalui 5 dimensi, yaitu: 1) Jumlah pekerjaan. Dimensi ini menunjukkan tentang jumlah pekerjaan yang dihasilkan oleh setiap individu.bekerja sesuai dengan kemampuan dan keahlian yang dimiliki. Berdasarkan persyaratan tersebut perusahaan bisa mengetahui jumlah karyawan yang dibutuhkan untuk melakukan tugasnya dan jumlah unit yang bisa diselesaikannya. 2) Kualitas pekerjaan Setiap karyawan harus memenuhi persyaratan tertentu untuk dapat menghasilkan pekerjaan yang sesuai dengan kualitas yang diharapkan oleh perusahaan. Setiap pekerjaan mempunyai standar kualitas tertentu yang harus disesuaikan oleh karyawan. Karyawan akan memiliki kinerja yang baik bila dapat mengerjakan pekerjaan sesuai dengan standar kualitas yang ditetapkannya. 3) Ketepatan Waktu. Jenis pekerjaan tertentu memiliki batas waktu dalam penyelesaian pekerjaan. Bila pekerjaan tidak terselesaikan sesuai dengan waktu yang ditentukan maka akan menghambat pekerjaan lainnya. Sehingga bisa mempengaruhi jumlah dan kualitas hasil pekerjaan.Suatu jenis produk tertentu hanya dapat digunakan sampai batas waktu tertentu, ini menuntut agar diselesaikan tepat waktu, karena berpengaruh atas penggunaanya. Pada dimensi ini karyawan dituntut untuk menyelesaikan pekerjaan tepat waktu. 4) 
Kehadiran. Suatu jenis pekerjaan tertentu menuntut kehadiran karyawan dalam mengerjakan sesuai dengan waktu yang ditentukan. Ada beberapa pekerjaan yang menuntut kehadiran karyawan selama 8 jam perhari dalam 5 hari kerja. Kinerja karyawan ditentukan tingkat kehadiran karyawan dalam mengerjakannya. 5) Kemampuan Kerja Sama, tidak semua pekerjaan dapat diselesaikan oleh satu orang saja. Ada pekerjaan yang harus dikerjakan secara berkelompok. Sehingga membutuhkan kerja sama yang baik untuk menyelesaikannya. Kinerja karyawan dapat dinilai dari kemampuan dalam berkerjasama dengan rekan sekerja lainnya

Data yang digunakan adalah data kuantitatif dan kualitatif dimana data kuantitatif yang digunakan dalam penelitian ini adalah data jumlah karyawan yang bekerja di PT. Pos Indonesia cabang Denpasar Renon dan hasil dari kuesioner yang merupakan jawaban responden, sementara data kualitatif yang digunakan dalam penelitian ini adalah gambaran umum lokasi penelitian dan data hasil wawancara karyawan PT. Pos Indonesia.

Sumber data dalam penelitian ini yaitu data primer dimana data penelitian yang diperoleh langsung dari asli (Indriantoro \& Supomo, 2016). Data yang dikumpulkan yaitu berupa pernyataan responden dalam menjawab kuesioner untuk menilai kepuasan, komitmen organisasional dan kinerja karyawan pada PT. Pos Indonesia dan data mengenai pencapaian kinerja karyawan pada PT. Pos Indonesia.

Populasi dalam penelitian ini adalah seluruh karyawan PT.Pos Indonesia cabang Renon Denpasar yang berjumlah 413 orang pada semua bidang dengan mengambil sampel 50 orang. Keputusan pengambilan sampel mengacu pada Roscoe, (1975) mengusulkan aturan berikut: Ukuran sampel lebih dari 30 dan kurang dari 500 adalah tepat untuk kebanyakan penelitian., Sampel di pecah ke dalam subsampel; (pria/wanita, junior/senior, dan sebagainya), ukuran sampel minimum 30 untuk tiap kategori adalah tepat., Dalam penelitian multivariat (termasuk analisis regresi berganda). Ukuran sampel sebaiknya beberapa kali (lebih disukai 10 kali atau lebih) lebih besar dari jumlah variabel dalam studi., Penelitian eksperimental sederhana dengan kontrol eksperimen yang ketat (matc pairs, dan sebagainya) penelitian yang sukses adalah mungkin dengan sampel ukuran kecil 10 atau 20.

Metode pengumpulan data yang digunakan dalam penelitian ini adalah:

a) Kuesioner, dilakukan dengan mengajukan daftar pernyataan kepada responden (karyawan) pada PT. Pos Indonesia Denpasar R enon untuk mendapatkan informasi yang dibutuhkan dalam menjawab permasalahan penelitian. Kuesioner yang disebarkan berupa pengukuran mengenai pengaruh kepuasan dan komitmen organisasional dan kinerja karyawan. b) Dokumentasi, dilakukan untuk memperoleh data mengenai historis keadaan PT. Pos Indonesia Denpasar Renon yang berupa sejarah singkat, struktur organisasi dan keadaan atau jumlah karyawannya.

Uji validitas digunakan untuk mengukur sah atau valid tidaknya suatu kuesioner. Suatu kuesioner dikatakan valid jika pertanyaan pada kuesioner mampu untuk mengungkapkan sesuatu yang akan diukur oleh kuesioner tersebut. Alat ukur dikatakan valid jika nilai korelasi antara item pertanyaan dengan totak 
item lebih dari 0,30 dimana probalitas yang diperoleh $<0,05$ maka dapat dinyatakan bahwa item pertanyaan tersebut adalah valid

Tabel 3.

Hasil uji validitas variabel Kepuasan Kerja

\begin{tabular}{lcl}
\hline Item & Koefisien Korelasi & Keterangan \\
\hline X1.1 & 0,922 & Valid \\
X1.2 & 0,947 & Valid \\
X1.3 & 0,840 & Valid \\
X1.4 & 0,882 & Valid \\
X2.5 & 0,787 & Valid \\
X1.6 & 0,713 & Valid \\
X1.7 & 0,545 & Valid \\
X1.8 & 0,813 & Valid \\
X1.9 & 0,785 & Valid \\
X1.10 & 0,742 & Valid \\
X1.11 & 0,641 & Valid \\
X1.12 & 0,818 & Valid \\
X1.13 & 0,765 & Valid \\
X1.14 & 0,947 & Valid \\
X1.15 & 0,940 & Valid \\
\hline
\end{tabular}

Sumber: Lampiran 2, 2019

Berdasarkan Tabel 3. diketahui bahwa seluruh indikator dalam variabel kepuasan kerja memiliki koefisien korelasi yang lebih besar dari 0,3. Jadi dapat disimpulkan bahwa seluruh indikator telah memenuhi syarat validitas data.

Tabel 4.

Hasil Uji Validitas Variabel Komitmen Organisasional $\left(\mathbf{X}_{2}\right)$

\begin{tabular}{lcl}
\hline Item & Koefisien Korelasi & Keterangan \\
\hline X2.1 & 0,838 & Valid \\
X2.2 & 0,873 & Valid \\
X2.3 & 0,849 & Valid \\
X2.4 & 0,842 & Valid \\
X2.5 & 0,928 & Valid \\
X2.6 & 0,838 & Valid \\
X2.7 & 0,851 & Valid \\
X2.8 & 0,880 & Valid \\
X2.9 & 0,811 & Valid \\
X2.10 & 0,692 & Valid \\
X2.11 & 0,880 & Valid \\
X2.12 & 0,736 & Valid \\
X2.13 & 0,735 & Valid \\
X2.14 & 0,752 & Valid \\
X2.15 & 0,793 & Valid \\
\hline Sumber: Lampiran 2,2019 &
\end{tabular}

Berdasarkan Tabel 4. diketahui bahwa seluruh indikator dalam variabel komitmen organisasional memiliki koefisien korelasi yang lebih besar dari 0,3. Jadi dapat disimpulkan bahwa seluruh indikator telah memenuhi syarat validitas data. 
Tabel 5.

Hasil Uji Validitas Variabel Kinerja Karyawan (Y)

\begin{tabular}{lcc}
\hline Item & Koefisien Korelasi & Keterangan \\
\hline Y1 & 0,709 & Valid \\
Y2 & 0,848 & Valid \\
Y3 & 0,873 & Valid \\
Y4 & 0,709 & Valid \\
Y5 & 0,848 & Valid \\
Y6 & 0,858 & Valid \\
Y7 & 0,707 & Valid \\
Y8 & 0,823 & Valid \\
Y9 & 0,864 & Valid \\
Y10 & 0,691 & Valid \\
Y11 & 0,722 & Valid \\
Y12 & 0,842 & Valid \\
Y13 & 0,680 & Valid \\
Y14 & 0,823 & Valid \\
Y15 & 0,859 & Valid \\
Y16 & 0,687 & Valid
\end{tabular}

Berdasarkan Tabel 5. diketahui bahwa seluruh indikator dalam variabel kinerja karyawan karyawan memiliki koefisien korelasi yang lebih besar dari 0,3. Jadi dapat disimpulkan bahwa seluruh indikator telah memenuhi syarat validitas data.

Hasil uji validitas variabel kepuasan kerja, komitemen organisasional dan kinerja karyawan. Seluruh indikator tiap-tiap variabel telah memenuhi syarat validitas dengan koefisien korelasi yang lebih besar dari 0,3. Hasil uji menunjukkan nilai Cronbaes's alpha untuk variabel kepuasan kerja sebesar 0,963, variabel komitmen organisasional sebesar 0,965, dan variabel kinerja karyawan sebesar 0,958. Sehingga dapat disimpulkan bahwa semua variabel telah memenuhi syarat reliabilitas data.

Uji reliabilitas adalah alat untuk mengukur suatu kuesioner yang merupakan indikator dari variabel atau konstruk.Untuk mengukur reliabilitas dengan uji statistik cronbach alpha lebih besar dari 0,60. Hasil reliabilitas ditunjukkan pada tabel berikut:

Tabel 6.

Uji Reliabilitas

\begin{tabular}{lcc}
\hline Variabel & Alpha Cronbach & Keterangan \\
\hline Kepuasan kerja & 0,963 & Reliabel \\
Komitmen organisasi & 0,965 & Reliabel \\
Kinerja karyawan & 0,958 & Reliabel \\
\hline Sumber: lampiran 3, 2019 & &
\end{tabular}

Hasil uji menunjukkan nilai cronbach alpha untuk variabel kepuasan kerja sebesar 0,963, variabel komitmen organisasional sebesar 0,965, dan variabel kinerja karyawan sebesar 0,958. Sehingga dapat disimpulkan bahwa semua variabel telah memenuhi syarat reliabilitas data. 
Teknik analisis data yang digunakan adalah analisi deskripsi dan analisis regresi linear berganda dengan persamaan sebagai berikut:

$Y=14,027+0,490 X_{1}+0,345 X_{2}$

Keterangan:

$\mathrm{Y}=$ Kinerja Karyawan

$\mathrm{X}_{1} \quad=$ Kepuasan Kerja

$\mathrm{X}_{2}=$ Komitmen Organisasional

$\beta 1, \beta 2=$ Koefisien regresi

e $\quad=\operatorname{error}$ (variabel bebas lain diluar model regresi)

\section{HASIL DAN PEMBAHASAN}

Dari hasil penelitian dapat dijelaskan gambaran mengenai karakteristik responden berdasarkan umur, jenis kelamin, pendidikan, status kepegawaian, masa kerja serta jabatan yang dapat dilihat pada Tabel 7.

Tabel 7.

Karakteristik Responden PT. Pos Indonessia Denpasar

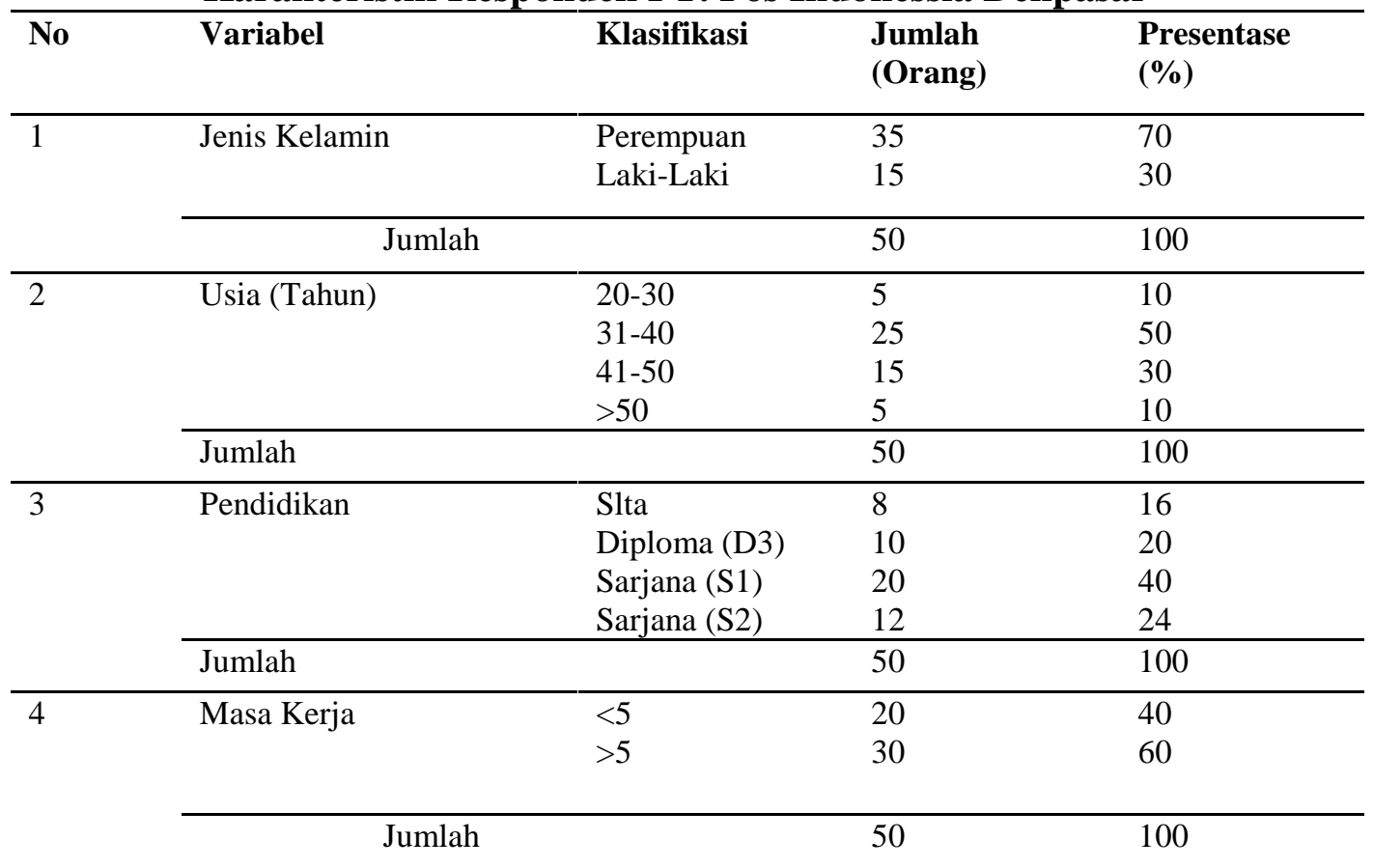

Sumber : PT. Pos Indonesia Tahun 2019

Berdasarkan jawaban responden dari segi umur didominasi dari $31-40$ tahun sebanyak 25 orang (50\%), hal demikian terjadi karena masa pekerja pada usia tersebut rata-rata berada di atas 5 tahun dan memiliki kemampuan dan kinerja yang cukup baik. Berdasarkan jenis kelamin kebanyakan karyawan laki-laki, sebanyak 35 orang $(70 \%)$, hal ini terjadi karena jasa yang diperlukan lebih banyak dilakukan oleh karyawan laki-laki sedangkan karyawan perempuan hanya 
diperuntukan di posisi-posisi tertentu. Berdasarkan pendidikan tanggapan responden didominasi lulusan S1 sebanyak 20 orang (40\%) hal ini terjadi karena pengalaman yang dimiliki oleh karyawan lulusan S1 rata-rata memenuhi standar perusahaan dan memiliki kinerja yang cukup baik. Karakteristik berdasarkan masa kerja kebanyakan $>5$ tahun sebanyak 30 orang (60\%), hal ini terjadi karena kebanyakan karyawanya merasa puas bekerja di PT. Pos Indonesia cabang Denpasar. Karakteristik berdasarkan status diketahui didominasi pegawai tetap sebanyak 40 orang $(80 \%)$, hal tersebut menunjukan kesetiaan karyawan untuk tetap bekerja. Karakteristik responden berdasarkan jabatan didominasi staf pelayanan sebanyak 17 orang (34\%). Hal ini terjadi karena status PT. Pos yang memprioritaskan karyawan dalam jasa layanan.

Persepsi responden terhadap variabel kepuasan kerja, komitmen organisasional, dan kinerja karyawan diuraikan secara berturut-turut pada Tabel 8 , 9 dan 10. Untuk mengukur bagaimana kepuasan kerja di PT. Pos Indonesia Denpasar, maka berikut hasil jawaban responden yang telah diolah sesuai kategori dan nilai skor. Deskripsi hasil jawaban responden kepuasan kerja pada Tabel 8. dapat dilihat.

Tabel 8.

Deskripsi Variabel Kepuasan Kerja

\begin{tabular}{|c|c|c|c|c|c|c|c|c|}
\hline \multirow[t]{2}{*}{ No } & \multirow[t]{2}{*}{ Pernyataan } & \multicolumn{5}{|c|}{$\begin{array}{c}\text { Proporsi Persepsi } \\
\text { Responden } \\
(\%)\end{array}$} & \multirow[t]{2}{*}{$\begin{array}{l}\text { Rata- } \\
\text { Rata }\end{array}$} & \multirow[t]{2}{*}{$\begin{array}{c}\text { Kriteri } \\
\text { a }\end{array}$} \\
\hline & & $\begin{array}{c}\text { ST } \\
\text { S }\end{array}$ & TS & $\mathrm{CS}$ & $\mathbf{S}$ & SS & & \\
\hline 1 & 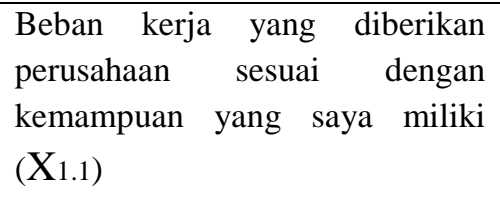 & - & - & 18 & 25 & 7 & 3,78 & Baik \\
\hline 2 & $\begin{array}{l}\text { Saya mendapat kesempatan yang } \\
\text { sama untuk meningkatkan karir } \\
\text { yang dipromosikan }\left(\mathrm{X}_{1.2}\right)\end{array}$ & - & 4 & 32 & 45 & 27 & 3,84 & Baik \\
\hline 3 & $\begin{array}{lcr}\text { Pekerjaan } & \text { yang } & \text { diberikan } \\
\text { perusahaan } & \text { sesuai } & \text { dengan } \\
\text { keinginan saya }\left(X_{1.3}\right) & \end{array}$ & - & 1 & 38 & 35 & 34 & 3,90 & Baik \\
\hline Rat & - rata variable kepuasan kerja sec & a ke: & eluru & & & & 3,91 & Baik \\
\hline
\end{tabular}

Sumber: Data primer diolah, 2019

Pertanyaan yang diajukan untuk mengukur variabel kepuasan kerja paling banyak menjawab pada skala 4 atau setuju, dengan nilai skor rata-rata untuk variabel kepuasan kerja sebesar 3,91 atau berada dalam kategori baik. Hal ini didukung dari pernyataan responden pelatihan pengembangan karir, kenyamanan bekerja memadai, gaji yang sesuai kerja dan gaji yang sesuai dengan beban kerja, 
namun masih ada beberapa tanggapan responden yang masih rendah hal ini dilihat dari beban kerja yg sesuai dengan kemampuan., kesempatan promosi jabatan dan kemampuan rekan dalam bekerja sama. Untuk mengukur bagaimana komitmen organisasional di PT. Pos Indonesia Denpasar, maka berikut hasil jawaban responden yang telah diolah sesuai kategori dan nilai skor.

Deskripsi hasil jawaban responden komitmen organisasional pada Tabel 9 dapat dilihat.

Tabel 9.

Deskripsi Variabel Komitmen Organisasional

\begin{tabular}{|c|c|c|c|c|c|c|c|c|}
\hline \multirow[t]{2}{*}{ No } & \multirow[t]{2}{*}{ Pernyataan } & \multicolumn{5}{|c|}{$\begin{array}{l}\text { Proporsi Persepsi } \\
\text { Responden } \\
(\%)\end{array}$} & \multirow[t]{2}{*}{$\begin{array}{l}\text { Rata- } \\
\text { Rata }\end{array}$} & \multirow[t]{2}{*}{$\begin{array}{c}\text { Kriteri } \\
\mathbf{a}\end{array}$} \\
\hline & & $\begin{array}{c}\text { ST } \\
\text { S }\end{array}$ & TS & CS & $\mathbf{S}$ & SS & & \\
\hline 1 & $\begin{array}{l}\text { Saya senang menghabiskan sisa } \\
\text { karir saya di perusahaan ini } \\
\text { (PT.Pos Indonesia) }\left(\mathrm{X}_{2.1}\right)\end{array}$ & - & - & 19 & 25 & 6 & 3,74 & Baik \\
\hline 2 & $\begin{array}{l}\text { Saya bangga membicarakan } \\
\text { perusahaan ini kepada orang lain } \\
\left(\mathrm{X}_{2.2}\right)\end{array}$ & - & - & 19 & 26 & 5 & 3,72 & Baik \\
\hline 3 & $\begin{array}{l}\text { Saya merasa masalah } \\
\text { perusahaan adalah masalah saya } \\
\text { sendiri }\left(\mathrm{X}_{2.3)}\right.\end{array}$ & - & - & 18 & 26 & 6 & 3,76 & Baik \\
\hline
\end{tabular}

Rata - rata variable komitmen organisasional secara keseluruhan $\quad 3,79 \quad$ Baik

Sumber: Data primer diolah, 2019

Pernyataan yang diajukan untuk mengukur variabel komitmen organisasional paling banyak menjawab pada skala 4 atau setuju, dengan nilai skor rata-rata untuk variabel komitmen organisasional sebesar 3,79 atau berada dalam kategori baik. Hal ini didukung dari pernyataan responden yang tidak akan meninggalkan pekerjaan walaupun ada penawaran, merasa terganggu apabila meninggalkan pekerjaanya, tidak akan meninggalkan pekerjaan sekalipun ingin dan merasa rugi jika meninggalkan pekerjaan sekarang, namun masih ada beberapa pernyataan yang masih rendah seperti karyawan yang merasa bangga dengan pekerjaannya, tetap setia pada perusahaan dan menjadi bagian dari perusahaan.

Untuk mengukur bagaimana kinerja karyawan di PT. Pos Indonesia Denpasar, maka berikut hasil jawaban responden yang telah diolah sesuai kategori dan nilai skor. Deskripsi hasil jawaban responden kinerja karyawan pada Tabel 10 dapat dilihat. 
Tabel 10.

Deskripsi Variabel Kinerja karyawan

\begin{tabular}{|c|c|c|c|c|c|c|c|c|}
\hline \multirow[t]{2}{*}{ No } & \multirow[t]{2}{*}{ Pernyataan } & \multicolumn{5}{|c|}{$\begin{array}{c}\text { Proporsi Persepsi } \\
\text { Responden } \\
(\%)\end{array}$} & \multirow[t]{2}{*}{$\begin{array}{l}\text { Rata- } \\
\text { Rata }\end{array}$} & \multirow[t]{2}{*}{$\begin{array}{c}\text { Kriteri } \\
\mathbf{a}\end{array}$} \\
\hline & & $\begin{array}{c}\text { ST } \\
\text { S }\end{array}$ & TS & CS & $\mathbf{S}$ & SS & & \\
\hline 1 & $\begin{array}{l}\text { Saya dapat menyelesaikan } \\
\text { pekerjaan sesuai target yang } \\
\text { ditetapkan perusahaan }\left(\mathrm{Y}_{1}\right)\end{array}$ & - & - & 6 & 42 & 2 & 3,92 & Baik \\
\hline 2 & $\begin{array}{l}\text { Saya dapat memenuhi beban } \\
\text { kerja yang di tetapkan } \\
\text { perusahaan (Y2) }\end{array}$ & - & - & 10 & 36 & 4 & 3,88 & Baik \\
\hline 3 & $\begin{array}{l}\text { Saya dapat menyelesaikan } \\
\text { pekerjaan tanpa banyak } \\
\text { kesalahan }\left(\mathrm{Y}_{3}\right)\end{array}$ & - & - & 16 & 29 & 5 & 3,78 & Baik \\
\hline Rat & - rata variable kinerja karyawan & cara & zesel & Iruha & & & 3,90 & Baik \\
\hline
\end{tabular}

Sumber: Data primer diolah, 2019

Berdasarkan hasil jawaban responden menunjukkan nilai rata-rata skor variabel kinerja karyawan sebesar 3,90 atau berada dalam kategori baik. Hal itu didukung dari karyawan yang mampu bekerja sama dengan rekannya, dan beberapa pernyataan lain juga memberikan pernyataan karyawan yang masuk dan pulang pada tepat waktunya, namun masih ada beberapa pernyataan yang masih rendah yaitu, menyelesaikan pekerjaan tepat waktu, menyelesaikan pekerjaan tanpa banyak salah dan menyelesaikan pekerjaan lebih awal.

Analisis regresi linear berganda dilakukan guna mengetahui adanya pengaruh variabel independen terhadap variabel dependen sehingga mampu menjawab rumusan penelitian yang sudah ditentukan Adapun hasil analisis linear berganda dapat dilihat pada tabel berikut:

Model yang digunakan dalam menganalisa pengaruh kepuasan kerja, komitmen organisasional, terhadap kinerja karyawan adalah model regresi linier berganda dengan bantuan SPSS versi 16.0 serta diuji dengan tingkat signifikansi $5 \%$. Dalam model regresi linier berganda ini, kepuasan kerja $\left(\mathrm{X}_{1}\right)$, komitmen organisasional $\left(\mathrm{X}_{2}\right)$, digunakan sebagai variabel bebas, sedangkan kinerja karyawan (Y) sebagai variabel terikat. Hasil regresi linear berganda disajikan pada Tabel 11.

Hasil uji normalitas dengan uji Kolmogorov-Smirnov diperoleh pada unstadarized residu nilai sig 0,618 lebih besar dari $\alpha=0,05$ artinya, bahwa berdistribusi normal. Hasil uji multikolinieritas menunjukkan tidak ada variabel bebas yang memiliki nilai tolerance kurang dari 10\% (0,100). Demikian juga dilihat dari nilai VIF yang semua variabel memiliki nilai VIF di bawah 10. Hal ini berarti dalam model regresi tidak terjadi multikolinieritas. Gejala 
heteroskedastisitas dapat dilihat dengan mendeteksi apakah ada tidaknya pola tertentu pada grafik (scater plot) yang dihasilkan, dimana sumbu x dan y yang telah diprediksi dan sumbu y adalah residual (y prediksi - y sesungguhnya) yang telah di studentized. Terlihat titik titik menyebar secara acak, tidak membentuk sebuah pola tertentu yang jelas, serta tersebar baik diatas maupun dibawah angka 0 pada sumbu Y.

Tabel 11.

Hasil Analisis Regresi Linier Berganda

\begin{tabular}{|c|c|c|c|c|c|c|}
\hline \multicolumn{2}{|c|}{ Model } & \multicolumn{2}{|c|}{$\begin{array}{l}\text { Unstandardized } \\
\text { Coefficients }\end{array}$} & \multirow{2}{*}{$\begin{array}{c}\text { Standardized } \\
\text { Coeffcients } \\
\text { Beta }\end{array}$} & \multirow[t]{2}{*}{$\mathbf{t}$} & \multirow[t]{2}{*}{ Sig. } \\
\hline & & B & $\begin{array}{c}\text { Std. } \\
\text { Error }\end{array}$ & & & \\
\hline \multirow{2}{*}{\multicolumn{2}{|c|}{$\begin{array}{c}\text { Kepuasan kerja } \\
\text { Komitmen organisasional }\end{array}$}} & 0,490 & 0,095 & 0,585 & 5,148 & 0,000 \\
\hline & & 0,345 & 0,096 & 0,411 & 3,618 & 0,001 \\
\hline Constant & $=$ & & & 14,027 & & \\
\hline$R$ Square & $=$ & & & 41,7 & & \\
\hline F Hitung & $=$ & & & 16,801 & & \\
\hline Signifikansi $\mathrm{F}$ & $=$ & & & 0,000 & & \\
\hline
\end{tabular}

Sumber: Data primer diolah, 2019

Berdasarkan hasil uji $\mathrm{F}$ diperoleh nilai signifikan $\mathrm{F}$ adalah sebesar 0,000 lebih kecil dari $0,05(\mathrm{~F}<\alpha)$ yang berarti kepuasan kerja $\left(\mathrm{X}_{1}\right)$ dan komitmen organisasional $\left(\mathrm{X}_{2}\right)$ secara bersama-sama berpengaruh signifikan terhadap kinerja karyawan (Y), dengan demikian persamaan regresi penelitian ini dinyatakan layak dianalisis lebih lanjut. Hasil uji ketetapan model perhitungan diperoleh F-hitung adalah 16,801 dan nilai sig $=0,00<0,05$ yang berarti model dapat dikatakan layak. Analisis ini dipergunakan untuk mengetahui variasi hubungan antara kepuasan kerja dan komitmen organisasi terhadap kinerja karyawan, secara simultan yang dinyatakan dalam presentase dan hasil perhitungan diperoleh koefisien determinasi adalah $41,7 \%$ berarti variasi hubungan antara kepuasan kerja dan komitmen organisasi terhadap kinerja cukup baik

Hasil uji Hipotesis menunjukkan hasil koefesien kepuasan kerja sebesar 0,490 dengan sig 0,00<0,05, yang berarti kepuasan kerja berpengaruh positif dan signifikan terhadap kinerja karyawan. Kemudian Pengujian hipotesis menunjukkan koefesien komitmen organisasional sebesar 0,345 dengan sig 0,00< 0,05 , yang berarti komitmen organisasional berpengaruh positif dan signifikan terhadap kinerja karyawan.

\section{HASIL DAN PEMBAHASAN}

Berdasarkan hasil uji Hipotesis menyatakan bahwa kepuasan kerja berpengaruh positif dan sigifikan terhadap kinerja karyawan. Hasil ini memberikan makna bahwa semakin baik (puas) karyawan dalam pekerjaannya maka semakin baik pula kinerja mereka, begitu pula sebaliknya semakin rendah kepuasan kerja karyawan semakin rendah kinerjanya. 
Kepuasan kerja merupakan salah satu faktor penting untuk mendapatkan hasil kerja yang optimal. Karyawan yang merasakan kepuasan kerja dalam pekerjaannya akan melakukan pekerjaanya dengan baik. Pada PT. Pos Indonesia kepuasan kerja yang dirasakan oleh karyawan cukup baik ini dilihat dari tanggapan responden mengenai pelatihan pengembangan karir yang sangat baik sehingga memberikan banyak peluang pengembangan karir bagi karyawan dengan gaji yang sesuai hasil dan gaji yang sesuai dengan beban kerja. Dalam penelitian Artadi (2015) tentang pengaruh kepuasan kerja dan beban kerja terhadap kinerja karyawan pada PT. Merapi Agung Lestari memperoleh hasil bahwa kepuasan kerja berpengaruh positif terhadap kinerja karyawan. Aji (2012) dengan judul pengaruh kepuasan kerja, loyalitas karyawan, dan komitmen organisasi terhadap kinerja karyawan (Studi kasus pada PT. Vision Land Bagian Packing) menunjukan bahwa kepuasan kerja berpengaruh positif terhadap kinerja karyawan. Kepuasan kerja memperlihatkan keadaan emosional karyawan terhadap perusahaan. Karyawan yang merasa puas dengan pekerjaanya akan termotivasi dalam bekerja. Kemudian akan meningkatkan kinerja karyawan PT. Pos Indonesia. Jika kepuasan kerja karyawan meningkat maka kinerja karyawan juga akan meningkat. Untuk itu perlu bagi perusahaan untuk memperhatikan kepuasan kerja yang dimiliki oleh karyawan. Indriani \& Wisnu (2011) dengan judul pengaruh budaya organisasi dan kepuasan kerja terhadap kinerja karyawan dengan komitmen organisasi sebagai variabel intervening pada Workshop SMK Katolik Santo Mikael Surakarta. Hasil dari penelitian ini membuktikan bahwa kepuasan kerja berpengaruh positif terhadap kinerja karyawan. Dengan adanya penelitian ini diharapkan perusahaan dapat mengetahui pengaruh tingkat kepuasan kerja karyawan terhadap tingkat kinerja karyawan. Namun masih ada beberapa faktor yang mempengaruhi kepuasan kerja yang dirasakan oleh karyawan. Salah satu faktor tersebut adalah karyawan yang merasa beban kerja tidak sesuai kemampuannya sehingga untuk memperoleh pengembangan karir yang jelas terhambat. Selain itu rekan kerja kurang memberikan dukungan dalam pekerjaan sehingga kemampuan rekan kerja untuk bekerja sama dalam mencapai target sangat rendah.

Berdasarkan hasil uji hipotesis dinyatakan komitmen organisasisional berpengaruh positif dan signifikan terhadap kinerja karyawan. Hasil ini memberikan makna bahwa semakin tinggi komitmen organisasional maka semakin tinggi pula kinerja karyawan, begitu pula sebaliknya semakin rendah komitmen organisasional maka semakin rendah kinerja karyawan. Komitmen organisasi merupakan komitmen yang dimiliki seorang karyawan terhadap perusahaan dimana karyawan tersebut bekerja. Hal ini dilihat dari tanggapan karyawan yang tidak meninggalkan pekerjaan meskipun ada penawaran sehingga mereka merasa terganggu apabila meninggalkan pekerjaan yang mereka lakukan sekarang. Dalam Kristiwardhana (2011) dalam penelitiannya yang berjudul analisis pengaruh motivasi dan komitmren organisasional terhadap kinerja. Aryo menyatakan dalam penelitiannya bahwa komitmen organisasional berpengaruh positif terhadap kinerja. Aulad \& Hidayati (2018) menyatakan bahwa komitmen organisasi, pengendalian intern dan akuntabilitas publik memiliki pengaruh yang signifikan terhadap kinerja karyawan (Studi Rumah sakit swasta di Propinsi 
Riau). Karyawan yang peduli terhadap nasib perusahaan tidak akan melanggar peraturan yang ditetapkan oleh perusahaan karena dapat merugikan perusahaan dan karyawan yang lain. Dalam penelitian yang dilakukan oleh Verawati \& Utomo (2011) dengan judul pengaruh komitmen organisasional, partisipasi dan motivasi terhadap kinerja karyawan menyatakan bahwa komitmen organisasional berpengaruh positif dan signifikan terhadap kinerja karyawan di PT. Bank Lippo Cabang Kudus. Akan tetapi pelanggaran standar Operasional perusahaan masih ditemukan pada karyawan PT. Pos Indonesia.. Karyawan memiliki loyalitas yang baik menunjukan adanya komitmen organisasi yang baik, Sedangkan loyalitas yang rendah menunjukan rendahnya komitmen organisasi yang dimilki oleh karyawan. Komitmen organisasi memilki timbal balik baik bagi karyawan dan perusahaan.

Karyawan yang memiliki komitmen yang tinggi cenderung memiliki rasa peduli terhadap nasib perusahaan. Selain itu karyawan juga merasa bangga menjadi bagian dari perusahaan atau organisasi. Namun disisi lain masih ada sebagian karyawan yang tidak setia berada di PT. Pos Indonesia Cabang Denpasar Renon sehingga sangat kecil kemungkinan untuk merasa bangga dengan pekerjaannya sekarang.

\section{SIMPULAN}

Berdasarkan hasil analisis dan pembahasan mengenai pengaruh kepuasan kerja dan komitmen organisasional terhadap kinerja karyawan PT. Pos Indonesia maka dapat ditarik kesimpulan sebagai berikut: Kepuasan kerja berpengaruh positif dan signifikan terhadap kinerja karyawan, artinya semakin tinggi kepuasan kerja maka semakin tinggi kinerja karyawan. Begitu pula sebaliknya semakin rendah kepuasan kerja maka semakin rendah kinerja karyawannya. Komitmen organiasional berpengaruh positif dan signifikan terhadap kinerja karyawan, artinya semakin tinggi komitmen organisasi maka semakin tinggi kinerja karyawan. Begitu juga sebaliknya semakin buruk komitmen organisasional maka semakin buruk kinerja karyawannya

Saran bagi perusahaan sebaiknya memberikan pekerjaan yang sesuai dengan kemampuan karyawan sehingga mampu mengebangkan karir dengan baik dan bisa mempromosikan pekerjaannya di PT Pos Indonesia cabang Denpasar dan untuk meningkatkan komitmen organisasional terhadap kinerja karyawan, hendaknya pihak manajemen PT. Pos Indonesia harus memberikan penghargaan kepada karyawan agar merasa bangga dengan pekerjaannya, sehingga tetap setia berada di perusahaan dan merasa menjadi bagian dari PT. Pos Indonesia cabang Denpasar.

\section{REFERENSI}

Afdalul Aulad, Nur Hidayati, J. (2018). Pengaruh Partisipasi Penyusunan Anggaran Terhadap Kinerja Aparat Pemerintah Daerah : Budaya Organisasi dan Komitmen Organisasi Sebagai Variabel Moderating. E-JRA, 07(07), 32-45. https://doi.org/10.1186/1476-4598-10-45 
Aji, B. B. (2012). Pengaruh Corporate Governance Terhadap Manajemen Laba Pada Perusahaan Manufaktur di Bursa Efek Indonesia. Skripsi. Sarjana Ekonomi Fakultas Ekonomika dan Bisnis Universitas Diponegoro.

Artadi, F. F. (2015). Pengaruh Kepuasan Kerja dan Beban Kerja terhadap Kinerja Karyawan pada PT. Merapi Agung Lestari. Skripsi. Sarjana Jurusan Manajemen Fakultas Ekonomi Universitas Negeri Yogyakarta.

Bangun, W. (2012). Manajemen Sumber Daya Manusia. Jakarta: Erlangga.

Desmiyawati, \& Witaliza, W. (2012). Pengaruh Komitmen Organisasi, Pengendalian Intern dan Akuntabilitas Publik terhadap Kinerja Organisasi. Pekbis Jurnal, 4(1), 26-33.

Imam, A., Raza, A., Tehseen Shah, F., \& Raza, H. (2013). Impact of job satisfaction on facet of organizational commitment (affective, continuance and normative commitment):A study of banking sector employees of Pakistan. World Applied Sciences Journal, 28(2), 271-277. https://doi.org/10.5829/idosi.wasj.2013.28.02.12468

Indriani, E., \& Wisnu, H. P. (2011). Pengaruh Budaya Organisasi Dan Kepuasan Kerja terhadap Kinerja Karyawan dengan Komitmen Organisasi sebagai Variabel Intervening pada Workshop SMK Katolik Santo Mikael Surakarta. EXCELLENT, 1(1), 20-21.

Indriantoro, N., \& Supomo, B. (2016). Metodologi Penelitian Bisnis untuk Akuntansi \& Manajemen. Yogyakarta: BPFE.

Kristiwardhana, A. (2011). Analisis Pengaruh Motivasi Kerja dan Komitmen Organisasional terhadap Kinerja Karyawan. Skripsi. Sarjana Ekonomi Fakultas Ekonomi Universitas Diponegoro.

Mangkunegara, A. P. (2013). Manajemen Sumber Daya Manusia Perusahaan. Bandung: Remaja Rosdakarya.

Meyer, J. P., \& Allen, N. J. (1997). Commitment in the workplace: Theory, research and application. London: SAGE Publications, Inc. https://doi.org/10.1016/s0099-1333(98)90184-7

Mohamed, M. S., \& Anisa, H. (2012). Relationship Between Organizational Commitment and Organizational Citizenship Behavior. The IUP Journal of Organizational Behavior, 11(3), 7-22. https://doi.org/10.5829/idosi.wjmbs.2013.1.1.1104

Priansa, D. J. (2014). Perencanaan dan Pengembangan SDM. Bandung: Alfabeta. Robbins, S., \& Judge, T. A. (2015). Perilaku Organisasi. Jakarta: Salemba Empat. 
Roscoe, J. T. (1975). Fundamental research statistics for the behavioral sciences. New York: Rinehart and Winston.

Verawati, Y., \& Utomo, J. (2011). Pengaruh Komitmen Organisasi, Partisipasi dan Motivasi terhadap Kinerja Karyawan pada PT. Bank Lippo tbk Cabang Kudus. Analisis Manajemen, 5(2), 1-8.

Zainal, V. R. (2014). Kepemimpinan dan Perilaku Organisasi. Jakarta: PT. Raja Grafindo Persada. 
E-Jurnal Manajemen, Vol. 9, No. 3, 2020 : 926-947 